\title{
Analisis Pemilihan Metode Quality of Service dengan Traffic Policing dan Traffic Shaping sebagai Pembanding Bandwidth pada Cisco Router Internet Service Provider
}

\author{
Nofita Rismawati ${ }^{1}$, Muhamad Femy Mulya ${ }^{2}$ \\ ${ }^{1}$ Program Studi Teknik Informatika, Universitas Indraprasta PGRI, Jakarta, Indonesia \\ ${ }^{2}$ Program Studi Sistem Informasi, Tanri Abeng University, Jakarta, Indonesia \\ novi.9001@gmail.com \\ femy.mulya@tau.ac.id \\ Diterima 30 April 2018 \\ Disetujui 8 Juni 2018
}

\begin{abstract}
Bandwidth is a carrying capacity of data carriers on a network connection, using units of time in speed. The cost of bandwidth procurement is very expensive and if it is not set up with management and hardware support, good software or brainware will cause huge losses. Therefore, a quality service standard must be created in an Internet Service provider known as Quality of Service (QoS). On a Cisco Router there are several methods of Quality of Service configured in such a way that the bandwidth of an ISP can be restricted and well managed. Traffic Policing and Traffic Shaping are two methods of Quality of Service that are widely used and each has advantages and disadvantages in terms of technical and non-technical. In this research will answer the use of the best Quality of Service method on Cisco ISP Router by using descriptive analysis through Quality of Service data analysis parameters.
\end{abstract}

\section{Index Terms-Bandwidth, Quality of Service}

\section{PENDAHULUAN}

Teknologi Jaringan Komputer di Indonesia telah menjadi kebutuhan yang cukup penting di berbagai bidang baik bidang bisnis, pendidikan, pemerintahan, sosial, dan keamanan. Teknologi jaringan yang paling berkembang hingga saat ini dipelopori oleh suatu konsep protokol yang bernama Transfer Control Protocol/Internet protocol (TCP/IP). TCP menyediakan layanan berorientasi koneksi pada lapisan aplikasi (Application Layer) protokol Internet yakni pengguna (client) dan penyedia (server) harus mengadakan sebuah hubungan/sambungan untuk pertukaran data.

Dalam hubungannya dengan manajemen bandwidth dan jaringan, TCP/IP didesain dengan tujuan utama untuk mendukung lalu lintas aplikasi pada jaringan. Aplikasi jaringan dan kebutuhan pengguna akan berubah seiring dengan kemajuan Teknologi Informasi dan Internet. Dengan bertambahnya pemakai yang menggunakan teknologi jaringan berkecepatan tinggi dan bertambah lebarnya jalur data, akan membuat semakin besarnya penggunaan bandwidth pada Teknologi Jaringan. Dengan demikian, hal ini berimbas pada beberapa masalah jaringan dalam jumlah yang lebih besar lagi yaitu memperlambat jalur data seperti delay queuing (antrian tunda), bottleneck (lebih banyak input dari pada kemampuan sebuah jalur data untuk mengirim) dan congestion (kemacetan) hingga deadlock (berhenti).

Kejadian-kejadian tersebut jika tidak di atur dengan manajemen yang baik membuat Internet Service Provider/ISP (penyedia layanan internet) dirugikan antara lain:

1. Terjadinya konsumsi bandwidth yang berlebihan (pemborosan bandwith).

2. Tertundanya bandwidth yang cukup lama (bandwidth delay) dalam perjalanan mencapai tujuan.

3. Menambah beban biaya pengadaan bandwidth.

4. Beban sistem pengawasan jaringan (Network Maintaining System) jadi lebih berat.

5. Menurunkan citra ISP dimata konsumen karena Quality of Service yang ditawarkan dan disetujui kurang ataupun tidak memuaskan.

6. Beban kerja Hardware Jaringan Komputer yang dipakai menjadi berat.

Kejadian yang akan menimpa pada konsumen pemakai jasa ISP antara lain :

1. Konsumen dirugikan karena biaya yang dibayar tidak sesuai dengan fasilitas yang didapat pada SLA (Service Level Agreement) yang disetujui.

2. Kecilnya jatah bandwith yang didapat sehingga akses internet atau pun ke jaringan tertentu menjadi lambat. 
3. Tidak konsistennya bandwidth (kadang naik, kadang turun) yang didapat sehingga mengganggu aktivitas user.

Untuk mengatasi masalah-masalah ini dibuatlah sebuah Standar Kualitas Layanan dalam mengatur teknologi jaringan agar sebuah ISP dapat berjalan dengan baik. Standar Kualitas Layanan yang disebutkan ini dikenal dengan nama Quality of Service atau dikenal dengan istilah QoS.

Analisis jaringan menggunakan QoS (Quality of Service) khususnya adalah Latency dan Throughput mampu memberikan analisis jaringan yang baik, dimana aspek ini yang sering digunakan didalam analisis jaringan. QoS didefinisikan sebagai sebuah mekanisme atau cara yang memungkinkan layanan dapat beroperasi sesuai dengan karakteristiknya masing-masing dalam jaringan IP (Internet Protocol) [2].

QoS mengacu pada kemampuan jaringan untuk menyediakan layanan yang lebih baik pada trafik jaringan tertentu melalui teknologi yang berbeda-beda. QoS menawarkan kemampuan untuk mendefinisikan atribut-atribut layanan jaringan yang disediakan, baik secara kualitatif maupun kuantitatif. Pada Tabel 1 diperlihatkan nilai presentase dari QoS [3].

Tabel 1. Kategori Quality of Service

\begin{tabular}{|c|c|c|}
\hline Nilai & Persentase (\%) & Indeks \\
\hline $3,8-4$ & $95-100$ & Sangat Baik \\
\hline $3-3,79$ & $75-94,75$ & Baik \\
\hline $2-2,99$ & $50-74,75$ & Cukup \\
\hline $1-1,99$ & $25-49,75$ & Buruk \\
\hline
\end{tabular}

Salah satu peralatan jaringan komputer yang dipakai oleh sebuah ISP untuk menerapkan QoS itu adalah Router buatan perusahaan Cisco. Dewasa ini dunia komputer disemarakkan dengan penggunaan internet yang dimungkinkan dengan memanfaatkan router untuk meneruskan informasi ke tempat yang berjauhan. Meski demikian, peranan router di dunia internet rupanya masih kurang diketahui banyak orang. Router, seperti juga komputer, memiliki perangkat keras yaitu peralatan router itu sendiri dan perangkat lunak yaitu Cisco Internetwork Operating System (Cisco IOS). Dalam penerapannya pada jaringan, router juga memiliki metode-metode dalam mengatur lalu lintas jaringan agar QoS dapat tercapai. Cisco IOS QoS menawarkan 2 macam mekanisme pengaturan lalu lintas jaringan yaitu Traffic Policing dan Traffic Shaping [1].

Penelitian ini penting dilakukan, karena pada penelitian-penelitian yang sudah dilakukan hanya sebatas penelitian mengenai pengukuran QoS (Quality of Service) secara langsung di lokasi atau area tertentu sebagai objek penelitiannya. Sedangkan pada penelitian ini, lebih berfokus untuk menganalisa dan merancang pemilihan metode penentu tingkat Quality of Service untuk Cisco Router pada ISP (Internet Service Provider).

Kemudian dalam merancang konsep Quality of Service untuk Cisco Router digunakan perbandingan metode Quality of Sevices yang sudah ada terhadap layanan ISP yang sedang berjalan agar dapat mengatur besar bandwidth yang dipakai, sehingga memperkecil beban biaya penyedia layanan ISP, dan menguntungkan konsumen/pemakai layanan tersebut, serta dapat memenuhi Term of Service dan SLA (Service Level Agreement) yang disetujui.

Dari beberapa uraian diatas, dapat dirumuskan pokok permasalahan sebagai berikut:

1. Bagaimana memilih dan merancang metode penentu tingkat Quality of Service untuk Cisco Router pada suatu perusahaan penyedia jasa layanan internet yang baik.

2. Bagaimana metode penentu tingkat Quality of Service untuk Cisco Router yang dapat mengalokasikan kebutuhan bandwith kepada pelanggan secara tepat dan efisien.

3. Apa kendala yang dihadapi dalam perancangan metode penentu tingkat Quality of Service untuk Cisco Router yang lebih baik serta bagaimana pemecahannya.

\section{TINJAUAN PUSTAKA}

A. Cisco Router

Fungsi utama Cisco Router adalah untuk meneruskan paket data dari suatu LAN ke LAN lainnya yang biasanya saling berjauhan. Selain itu, Cisco Router menggunakan tabel dan protokol routing yang berfungsi untuk mengatur lalu lintas data. Paket data yang tiba di router diperiksa dan diteruskan ke alamat yang dituju. Agar paket data yang diterima dapat sampai ke tujuannya dengan cepat, router harus memproses data tersebut dengan sangat cepat, untuk itu Cisco membutuhkan Central Processing Unit (CPU), seperti yang digunakan didalam komputer untuk memproses lalu lintas data tersebut dengan sangat cepat [2].

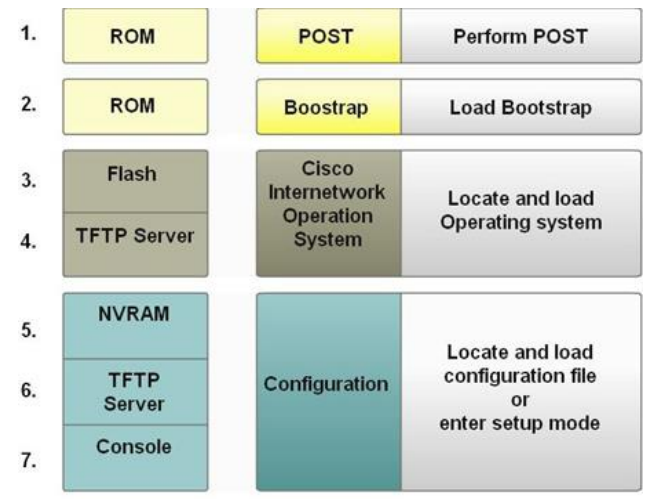

Gambar 1. Komponen Cisco Router [2]. 


\section{B. Quality of Service (QoS)}

Quality of Service adalah kemampuan sebuah jaringan untuk menyediakan pelayanan yang lebih baik ke network traffic yang dipilih dari sekian banyak penggunaan teknologi termasuk Frame Relay, Asynchronous Transfer Mode (ATM), Ethernet \& 802.1 Networks, SONET, dan IP-Routed networks. Fasilitas yang dimiliki QoS menyediakan layanan network yang lebih baik dan lebih dapat diramalkan dengan [3]:

1. Mendukung dedicated bandwidth.

2. Menghindari dan mengatur network congestion (kemacetan).

3. Membentuk network traffic.

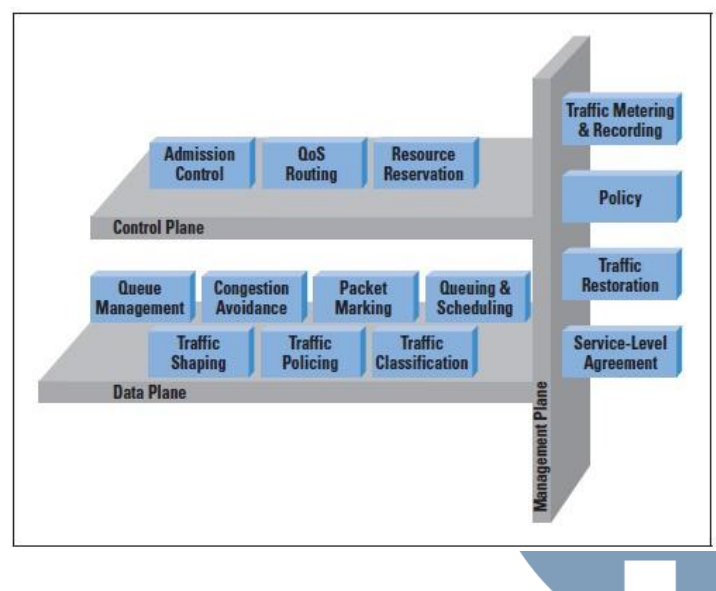

Gambar 2. Arsitektur QoS [4].

Data plane berisi mekanisme-mekanisme yang beroperasi secara langsung terhadap aliran data, antara lain:

1. Quеuе Management (manajemen antrian). Algoritmanya mengelola panjang antrian paket dengan menghapus paket-paket bila layak untuk dihilangkan. Hal ini untuk menghindari kemacetan pada aliran data.

2. Algoritma Queue \& Scheduling (antrian \& penjadwalan). Menentukan paket mana yang akan dikirim selanjutnya. Hal ini bertujuan untuk mengelola alokasi kapasitas transmisi dalam aliran data.

3. Congestion Avoidance (pencegahan kemacetan). Untuk menjaga beban jaringan sesuai dengan kapasitasnya, agar jaringan dapat beroperasi pada level kinerja yang sesuai.

4. Packet Marking berfungsi untuk menandai tingkat kepentingan suatu paket sehingga paket tersebut berhak menerima perlakuan khusus dalam jaringan, atau menandai bahwa paket tersebut tidak penting sehingga layak dibuang ketika kemacetan dalam jaringan terjadi.

5. Traffic classification mengklafikasi paket kepada suatu kelas traffic, misalnya berdasarkan alamat sumber dan tujuan, konten paket, dan tanda QoS pada paket.

6. Traffic policing berfungsi mengontrol lalu lintas atau traffic pada sebuah jaringan.

7. Traffic shaping mengontrol kecepatan dan volume traffic yang masuk dan melintasi jaringan berbasis per aliran data.

Control plane berkaitan dengan pembuatan dan pengelolaan "jalan" di mana data pengguna mengalir. Mekanismenya antara lain:

1. Admission control menentukan traffic pengguna seperti apa yang berhak memasuki jaringan.

2. QoS routing menentukan jalur jaringan yang dapat mengakomodasi QoS yang diminta dari suatu aliran data.

3. Resource reservation memesan sumber daya jaringan berdasarkan permintaan untuk menghasilkan kinerja jaringan yang diinginkan oleh suatu aliran data.

Management plane berisi mekanisme yang memengaruhi mekanisme control dan data plane, yaitu:

1. SLA (Service Level Agreement), merupakan perjanjian antara pelanggan dan penyedia layanan yang menspesifikasikan tingkat ketersediaan, kemampuan layanan, operasi, performa, dan sifat-sifat layanan lainnya. Contoh SLA: keterlambatan maksimal $45 \mathrm{~ms}$, rerata paket hilang kurang dari $0,1 \%$.

Traffic metering \& recording memonitor sifatsifat dinamis arus traffic, misalnya kecepatan data dan laju data yang hilang.

3. Traffic restoration mengacu pada respons jaringan terhadap kegagalan.

4. Policy mengacu pada suatu set peraturan untuk administrasi, pengelolaan, dan kontrol akses ke sumber daya jaringan.

\section{Wireshark}

Wireshark merupakan sebuah software sniffer freeware yang dapat didownload dengan mudah di www.wireshark.org. Program sniffer adalah program yang dapat digunakan apabila kita ingin "mengintip/mengendus/sniff" sebuah jaringan, baik Ethernet maupun non-ethernet. Wireshark adalah packet analyzer gratis dan open - Source. Tools ini seringkali digunakan untuk menemukan masalah pada jaringan, pengembangan perangkat lunak dan protokol komunikasi, dan pendidikan. Wireshark bersifat cross - platform dan menggunakan pcap untuk mengcapture paket jaringan. Wireshark dapat berjalan pada hampir semua sistem operasi yang tersedia. 
Wireshark merupakan salah satu aplikasi open source yang digunakan sebagai alat analisa protokol jaringan.

Wireshark dikembangkan oleh lebih dari 600 pengembang selama lebih dari sembilan tahun dan tidak kurang 300.000 download per bulannya. Karena wireshark open source maka bebas untuk digunakan, didistribusikan dan dimodifikasi dengan menggunakan lisensi GNU (General Public License) [5].

Fungsi wireshark yaitu menganalisa data yang melintas pada media transmisi dan mempresentasikan informasi yang didapat secara logis sesuai dengan model OSI Reference Model [6]. Hal-hal yang dapat dilakukan wireshark:

- Network Administrator menggunakan wireshark untuk troubleshoot masalah jaringan.

- Network Security menggunakan wireshark untuk memecahkan masalah security jaringan.

- Pengembang menggunakan untuk debug implementasi protocol.

- Pengguna menggunakannya/untuk belajar protocol jaringan internalnya.

- Mendiagnosa permasalahan.

- Meng-capture informasi jaringan.

- Melakukan decode pada frame.

- Melakukan filtering pada trace file

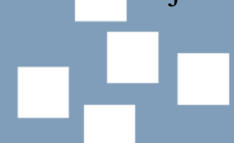

D. Parameter-parameter QoS (Quality of Service) Parameter Quality of Service terdiri dari :

\section{Throughput}

Throughput yaitu kecepatan (rate) transfer data efektif, yang diukur dalam kbps (kilo bit per second). Throughput adalah jumlah total kedatangan paket yang sukses yang diamati pada tujuan selama interval waktu tertentu dibagi oleh durasi interval waktu tersebut. Kategori Throughput diperlihatkan di Tabel 2 [3].

Tabel 2. Kategori Throughput

\begin{tabular}{|l|c|c|}
\hline $\begin{array}{c}\text { Kategori } \\
\text { Throughput }\end{array}$ & $\begin{array}{c}\text { Throughput } \\
\text { (kbps) }\end{array}$ & Indeks \\
\hline Sangat Baik & 1024 & 4 \\
\hline Baik & 512 & 3 \\
\hline Cukup & 256 & 2 \\
\hline Buruk & $<64$ & 1 \\
\hline
\end{tabular}

\section{Packet Loss}

Packet Loss merupakan suatu parameter yang menggambarkan suatu kondisi yang menunjukkan jumlah total paket yang hilang dapat terjadi karena collision dan congestion pada jaringan [3]. Indeks dan kategori packet loss ditunjukkan pada Tabel 3.

Tabel 3. Kategori Packet Loss

\begin{tabular}{|l|c|c|}
\hline Kategori Degredasi & Packet Loss (\%) & Indeks \\
\hline Sangat Baik & 0 & 4 \\
\hline Baik & 3 & 3 \\
\hline Cukup & 15 & 2 \\
\hline Buruk & 25 & 1 \\
\hline
\end{tabular}

\section{Delay (Latency)}

Delay (Latency) merupakan waktu yang dibutuhkan data untuk menempuh jarak dari asal ke tujuan. Delay dapat dipengaruhi oleh jarak, media fisik, congesti atau juga waktu proses yang lama. Pada Tabel 4 diperlihatkan kategori dari delay dan besar delay [3].

Tabel 4. Kategori Delay (Latency)

\begin{tabular}{|l|c|c|}
\hline Kategori Latency & Besar Delay (ms) & Indeks \\
\hline Sangat Baik & $<150 \mathrm{~ms}$ & 4 \\
\hline Baik & $150 \mathrm{~ms} \mathrm{~s} / \mathrm{d} 300 \mathrm{~ms}$ & 3 \\
\hline Cukup & $300 \mathrm{~ms} \mathrm{~s} / \mathrm{d} 450 \mathrm{~ms}$ & 2 \\
\hline Buruk & $>450 \mathrm{~ms}$ & 1 \\
\hline
\end{tabular}

\section{Jitter atau Variasi Kedatangan Paket}

Jitter diakibatkan oleh variasi-variasi dalam panjang antrian, dalam waktu pengolahan data, dan juga dalam waktu penghimpunan ulang paket-paket diakhir perjalanan jitter. Jitter lazimnya disebut variasi delay, berhubungan erat dengan latency, yang menunjukkan banyaknya variasi delay pada transmisi data di jaringan yang diperlihatkan pada Tabel 5 [3].

Tabel 5. Kategori Jitter

\begin{tabular}{|l|c|c|}
\hline \multicolumn{1}{|c|}{ Kategori Jitter } & Jitter (ms) & Indeks \\
\hline Sangat Baik & $0 \mathrm{~ms}$ & 4 \\
\hline Baik & $0 \mathrm{~ms} \mathrm{~s} / \mathrm{d} 75 \mathrm{~ms}$ & 3 \\
\hline Cukup & $75 \mathrm{~ms} \mathrm{~s} / \mathrm{d} 125 \mathrm{~ms}$ & 2 \\
\hline Buruk & $125 \mathrm{~ms} \mathrm{~s} / \mathrm{d} 225 \mathrm{~ms}$ & 1 \\
\hline
\end{tabular}

\section{METODE PENELITIAN}

Dalam merancang konsep penentu metode Quality of Service terbaik untuk Cisco Router pada Internet Service Provider (ISP), pada penelitian ini menggunakan analisis deskriptif melalui parameter analisis data QoS (Quality of Service) yaitu : 


$$
\text { Throughput }=\frac{\text { Jumlah Data Dikirim }}{\text { Waktu Pengiriman Data }}
$$

$$
\text { Packet Loss }=\left(\frac{\text { data yang dikirim-paket data yang diterima }}{\text { paket data yang dikirim }}\right) \times 100 \%
$$

Total Delay

Delay $=$

Total Paket yang diterima

Total Variasi Delay

Jitter

$$
=\overline{\text { Total Paket yang diterima }}
$$

\section{HASIL DAN PEMBAHASAN}

A. Analisis Perbandingan Traffic Policing dengan Traffic Shaping untuk pembatasan bandwidth

Dari hasil ujicoba pengiriman data pada cisco router dengan sumbu y sebagai traffic dan sumbu $\mathrm{x}$ sebagai time, pada metode traffic policing menghasilkan bursting (lonjakan bandwidth). Ketika traffic rate mencapai batasan maksimum dari yang dikonfigurasikan, kemudian kelebihan traffic akan dibuang atau dibatasi. Hasilnya adalah nilai keluaran (output rate) yang muncul berupa grafik lancip tidak beraturan menjadi grafik dengan ujung datar tidak beraturan.
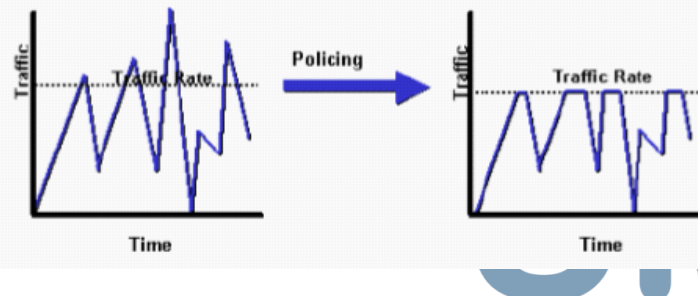

Gambar 3. Grafik Traffic Policing

Sedangkan pada metode traffic shaping mempertahankan kelebihan paket dalam sebuah antrian (quеue) dan kemudian menjadwalkan dari kelebihan paket tersebut untuk ditransmisikan pada waktu yang ditentukan akan datang, Hasil dari traffic shaping ini adalah sebuah paket dengan nilai keluaran yang mulus. Sebagai tambahan, traffic shaping memerlukan sebuah fungsi penjadwalan (scheduling function) untuk transmisi yang akan datang pada semua paket yang tertunda (delayed packets).

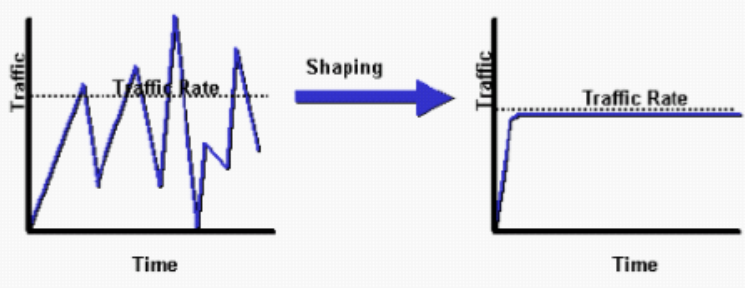

Gambar 4. Grafik Traffic Shaping

\section{B. Perbandingan Teknis antara Traffic Policing dan Traffic Shaping}

Dari hasil ujicoba pengiriman paket data dengan metode traffic policing dan metode traffic shaping pada cisco router dengan menggunakan beberapa parameter pengujian, maka dihasilkan perbandingan sebagai berikut:

\begin{tabular}{|c|c|c|}
\hline Parameter & Traffic Policing & Traffic Shaping \\
\hline Objective & $\begin{array}{l}\text { Paket yang melampaui } \\
\text { batas akan terbuang. } \\
\text { Tidak memiliki buffer } \\
\text { (ruang penyimpanan). } \\
\text { Walaupun tidak } \\
\text { memiliki buffer, } \\
\text { sebuah mekanisme } \\
\text { antrian terkonfigurasi } \\
\text { dapat diaplikasikan } \\
\text { terhadap paket yang } \\
\text { harus diantrikan pada } \\
\text { saat menunggu untuk } \\
\text { diumumkan pada } \\
\text { lapisan antarmuka. }\end{array}$ & $\begin{array}{l}\text { Buffer dan Queue } \\
\text { (antrian) menyimpan } \\
\text { paket yang melampaui } \\
\text { batasan yang } \\
\text { ditentukan }\end{array}$ \\
\hline $\begin{array}{l}\text { Token } \\
\text { Refresh } \\
\text { Rate }\end{array}$ & $\begin{array}{l}\text { Stabil berdasarkan } \\
\text { formula. } \\
1 \text { / } \\
\text { committed } \\
\text { information } \\
\text { rate }\end{array}$ & $\begin{array}{l}\text { Meningkat dari awal } \\
\text { mula interval waktu. } \\
\text { (Diperlukannya nilai } \\
\text { minimum dari interval } \\
\text { tersebut) }\end{array}$ \\
\hline Token Value & $\begin{array}{l}\text { Dikonfigurasikan } \\
\text { dalam bytes }\end{array}$ & $\begin{array}{l}\text { Dikonfigurasikan } \\
\text { dalam bits per second }\end{array}$ \\
\hline $\begin{array}{l}\text { Configuratio } \\
\text { n Options }\end{array}$ & $\begin{array}{l}\text { Perintah traffic } \\
\text { police } \text { dalam MCQ } \\
\text { (Modular Quality } \\
\text { of Service } \\
\text { Command-line) } \\
\text { mengimplementasi } \\
\text { kan class-based } \\
\text { shaping. } \\
\text { - Perintah rate-limit } \\
\text { mengimplementasi } \\
\text { kan Committed } \\
\text { Access Rate (CAR). }\end{array}$ & 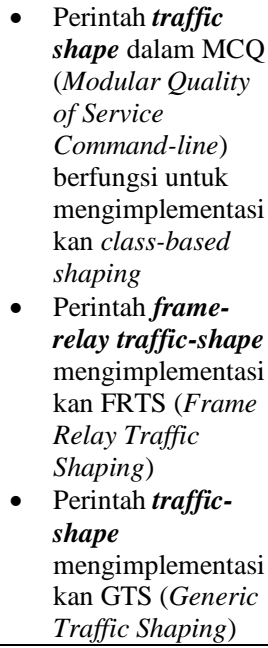 \\
\hline $\begin{array}{l}\text { Applicable } \\
\text { on Inbound }\end{array}$ & $\mathrm{Ya}$ & Tidak \\
\hline $\begin{array}{l}\text { Applicable } \\
\text { on } \\
\text { Outbound }\end{array}$ & $\mathrm{Ya}$ & $\mathrm{Ya}$ \\
\hline Bursts & $\begin{array}{l}\text { Menghasilkan } \\
\text { lonjakan. Tidak } \\
\text { melakukan } \\
\text { pemerataan. }\end{array}$ & $\begin{array}{l}\text { Mengendalikan } \\
\text { lonjakan dengan } \\
\text { meratakan nilai } \\
\text { keluaran kira-kira } \\
\text { sebanyak } 8 \text { interval. } \\
\text { Menggunakan sebuah } \\
\text { sistem antrian untuk } \\
\text { menunda traffic, } \\
\text { sehingga } \\
\text { menghasilkan efek }\end{array}$ \\
\hline
\end{tabular}

Tabel 6. Perbandingan Teknis antara Traffic Policing dan Traffic Shaping 
ISSN 2085-4579

\begin{tabular}{|c|c|c|}
\hline Parameter & Traffic Policing & Traffic Shaping \\
\hline & & yang mulus. \\
\hline Advantages & $\begin{array}{l}\text { Mengendalikan } \\
\text { batasan keluaran lewat } \\
\text { pemotongan paket } \\
\text { berlebih dan } \\
\text { menghindari antrian }\end{array}$ & $\begin{array}{l}\text { Sedikit memotong } \\
\text { paket yang berlebih } \\
\text { semenjak paket } \\
\text { berlebih tersebut } \\
\text { disimpan. Paket } \\
\text { tersimpan itu masuk } \\
\text { ke dalam jalur antrian. } \\
\text { Hilangnya paket dapat } \\
\text { terjadi jika traffic yang } \\
\text { terpakai sedang dalam } \\
\text { batasan yang tinggi. }\end{array}$ \\
\hline $\begin{array}{l}\text { Disadvantag } \\
\text { es }\end{array}$ & $\begin{array}{l}\text { Paket yang hilang } \\
\text { (ketika } \\
\text { dikonfigurasikan), } \\
\text { Mengendalikan ukuran } \\
\text { jendela TCP dan } \\
\text { mengurangi } \\
\text { keseluruhan batasan } \\
\text { keluaran yang } \\
\text { terpengaruh traffic } \\
\text { stream. Ukuran } \\
\text { lonjakan yang cukup } \\
\text { besar dapat } \\
\text { menyebabkan } \\
\text { hilangnya paket } \\
\text { berlebih dan } \\
\text { mengendalikan } \\
\text { keseluruhan batasan } \\
\text { keluaran, secara } \\
\text { terfokus dengan } T C P \text { - } \\
\text { based flows. }\end{array}$ & $\begin{array}{l}\text { Dapat memakan waktu } \\
\text { yang cukup lama pada } \\
\text { antrian, jika terdapat } \\
\text { antrian yang cukup } \\
\text { dalam }\end{array}$ \\
\hline $\begin{array}{l}\text { Optional } \\
\text { Packet } \\
\text { Remarking }\end{array}$ & $\begin{array}{l}\text { Ya (dengan fasilitas } \\
\text { Committed Access } \\
\text { Rate) }\end{array}$ & Tidak \\
\hline
\end{tabular}

C. Analisis Deskriptif Perbandingan Traffic Policing dan Traffic Shaping

Berdasarkan hasil uji coba sebanyak 100 kali percobaan pengiriman data dengan sample jumlah data yang dikirim sebanyak 100000 kbps untuk setiap uji coba pengiriman data pada cisco router milik internet service provider, maka didapat parameter data rata-rata untuk metode traffic policing dan traffic shaping pada tabel 7 berikut.

Tabel 7. Parameter Data Untuk Perhitungan QoS

\begin{tabular}{|c|l|c|c|}
\hline \multirow{2}{*}{ No } & \multicolumn{1}{|c|}{$\begin{array}{c}\text { Parameter Data } \\
\text { untuk Perhitungan } \\
\text { QoS }\end{array}$} & \multicolumn{2}{|c|}{$\begin{array}{c}\text { Rata-Rata Nilai dari 100 kali } \\
\text { Percobaan dengan sample } \\
\text { jumlah data yang dikirim } \\
\text { sebanyak 100000 kbps }\end{array}$} \\
\cline { 3 - 4 } & $\begin{array}{c}\text { Traffic } \\
\text { Policing }\end{array}$ & $\begin{array}{c}\text { Traffic } \\
\text { Shaping }\end{array}$ \\
\hline 1 & $\begin{array}{l}\text { Jumlah data yang } \\
\text { dikirim (kbps) }\end{array}$ & $100000 \mathrm{kbps}$ & $100000 \mathrm{kbps}$ \\
\hline 2 & $\begin{array}{l}\text { Waktu pengiriman } \\
\text { data (second) }\end{array}$ & $110 \mathrm{sec}$ & $97 \mathrm{sec}$ \\
\hline 3 & $\begin{array}{l}\text { Paket data yang } \\
\text { diterima (kbps) }\end{array}$ & $99985 \mathrm{kbps}$ & $100000 \mathrm{kbps}$ \\
\hline 4 & Total Delay (second) & $13998 \mathrm{sec}$ & $12000 \mathrm{sec}$ \\
\hline 5 & $\begin{array}{l}\text { Total variasi Delay } \\
\text { (second) }\end{array}$ & $1001 \mathrm{sec}$ & $0 \mathrm{sec}$ \\
\hline
\end{tabular}

Setelah memperoleh parameter data rata-rata dari hasil percobaan, maka akan dilakukan perhitungan QoS (Quality of Service) untuk metode traffic policing dan traffic shaping, adapun parameter yang dihitung seperti: Throughput, Packet Loss, Delay (Latency) dan Jitter.

Dari hasil perhitungan QoS (Quality of Service) untuk parameter Throughput, pada Tabel 8 didapat nilai persentase (\%) untuk metode traffic policing sebesar 88,78\% dan traffic shaping sebesar 100\%.

Tabel 8. Perhitungan Throughput pada QoS

\begin{tabular}{|c|l|c|c|}
\hline \multirow{2}{*}{ No } & \multirow{2}{*}{$\begin{array}{c}\text { Parameter Quality of } \\
\text { Service }\end{array}$} & \multicolumn{2}{|c|}{$\begin{array}{c}\text { Metode QoS yang Diukur Pada } \\
\text { Cisco Router }\end{array}$} \\
\cline { 3 - 4 } & \multicolumn{1}{|c|}{$\begin{array}{c}\text { Traffic } \\
\text { Policing }\end{array}$} & $\begin{array}{c}\text { Traffic } \\
\text { Shaping }\end{array}$ \\
\hline 1 & Throughput (kbps) & $909,09 \mathrm{kbps}$ & $1030,93 \mathrm{kbps}$ \\
\hline 2 & Indeks & 3 & 4 \\
\hline 3 & Kategori Throughput & Baik & Sangat Baik \\
\hline 4 & $\begin{array}{l}\text { Nilai Persentase (\%) } \\
\text { Throughput }\end{array}$ & $88,78 \%$ & $100 \%$ \\
\hline
\end{tabular}

Dari hasil perhitungan QoS (Quality of Service) untuk parameter Packet Loss, pada Tabel 10 didapat nilai persentase (\%) untuk metode traffic policing sebesar 99,98\% dan traffic shaping sebesar 100\%.

Tabel 10. Perhitungan Packet Loss pada QoS

\begin{tabular}{|c|l|c|c|}
\hline \multirow{2}{*}{ No } & \multirow{2}{*}{$\begin{array}{c}\text { Parameter Quality of } \\
\text { Service }\end{array}$} & \multicolumn{2}{|c|}{$\begin{array}{c}\text { Metode QoS yang Diukur Pada } \\
\text { Cisco Router }\end{array}$} \\
\cline { 3 - 4 } & \multicolumn{2}{|c|}{$\begin{array}{c}\text { Traffic } \\
\text { Policing }\end{array}$} & $\begin{array}{c}\text { Traffic } \\
\text { Shaping }\end{array}$ \\
\hline 1 & Packet Loss (\%) & $0,02 \%$ & $0 \%$ \\
\hline 2 & Indeks & 4 & 4 \\
\hline 3 & $\begin{array}{l}\text { Kategori Packet Loss / } \\
\text { Degredasi }\end{array}$ & Sangat Baik & Sangat Baik \\
\hline 4 & $\begin{array}{l}\text { Nilai Persentase (\%) } \\
\text { Packet Loss }\end{array}$ & $99,98 \%$ & $100 \%$ \\
\hline
\end{tabular}

Dari hasil perhitungan QoS (Quality of Service) untuk parameter Delay, pada Tabel 11 didapat nilai persentase (\%) untuk metode traffic policing sebesar 84,94\% dan traffic shaping sebesar 100\%.

Tabel 11. Perhitungan Packet Loss pada QoS

\begin{tabular}{|c|l|c|c|}
\hline \multirow{2}{*}{ No } & \multirow{2}{*}{$\begin{array}{c}\text { Parameter Quality } \\
\text { of Service }\end{array}$} & $\begin{array}{c}\text { Metode QoS yang Diukur Pada } \\
\text { Cisco Router }\end{array}$ \\
\cline { 3 - 4 } & & $\begin{array}{c}\text { Traffic } \\
\text { Policing }\end{array}$ & $\begin{array}{c}\text { Traffic } \\
\text { Shaping }\end{array}$ \\
\hline 1 & Delay (ms) & $172,59 \mathrm{~ms}$ & $122 \mathrm{~ms}$ \\
\hline 2 & Indeks & 3 & 4 \\
\hline 3 & Kategori Delay & Baik & Sangat Baik \\
\hline 4 & $\begin{array}{l}\text { Nilai Persentase (\%) } \\
\text { Delay }\end{array}$ & $84,94 \%$ & $100 \%$ \\
\hline
\end{tabular}

Dari hasil perhitungan QoS (Quality of Service) untuk parameter Jitter, pada Tabel 12 didapat nilai persentase (\%) untuk metode traffic policing sebesar 99,98\% dan traffic shaping sebesar 100\%. 
Tabel 12. Perhitungan Jitter pada QoS

\begin{tabular}{|c|l|c|c|}
\hline \multirow{2}{*}{ No } & \multirow{2}{*}{$\begin{array}{c}\text { Parameter Quality } \\
\text { of Service }\end{array}$} & \multicolumn{2}{|c|}{$\begin{array}{c}\text { Metode QoS yang Diukur Pada } \\
\text { Cisco Router }\end{array}$} \\
\cline { 3 - 4 } & \multicolumn{1}{|c|}{$\begin{array}{c}\text { Traffic } \\
\text { Policing }\end{array}$} & $\begin{array}{c}\text { Traffic } \\
\text { Shaping }\end{array}$ \\
\hline 1 & Jitter (ms) & $0,01 \mathrm{~ms}$ & $0 \mathrm{~ms}$ \\
\hline 2 & Indeks & 3 & 4 \\
\hline 3 & Kategori Jitter & Baik & Sangat Baik \\
\hline 4 & $\begin{array}{l}\text { Nilai Persentase (\%) } \\
\text { Jitter }\end{array}$ & $99,99 \%$ & $100 \%$ \\
\hline
\end{tabular}

Pada Tabel 13 diperoleh persentase (\%) rata-rata QoS dari beberapa parameter seperti: Throughput, Packet Loss, Delay (Latency) dan Jitter. Adapun ratarata nilai persentase $(\%)$ QoS, untuk metode traffic policing sebesar 93,42\% dengan Indeks QoS Baik dan traffic shaping sebesar $100 \%$ dengan Indeks QoS Sangat Baik.

Tabel 13. Rata-Rata QoS untuk metode traffic policing dan traffic shaping

\begin{tabular}{|c|l|c|c|}
\hline \multirow{2}{*}{ No } & \multirow{2}{*}{$\begin{array}{c}\text { Parameter } \\
\text { Quality of Service }\end{array}$} & \multicolumn{2}{|c|}{$\begin{array}{c}\text { Metode Qos yang Diukur Pada } \\
\text { Cisco Router }\end{array}$} \\
\cline { 3 - 4 } & & Traffic Policing & $\begin{array}{c}\text { Traffic } \\
\text { Shaping }\end{array}$ \\
\hline 1 & Throughput & $88,78 \%$ & $100 \%$ \\
\hline 2 & Packet Loss & $99,98 \%$ & $100 \%$ \\
\hline 3 & Delay & $84,94 \%$ & $100 \%$ \\
\hline 4 & Jitter & $99,99 \%$ & $100 \%$ \\
\hline 5 & Indeks QoS & Baik & Sangat Baik \\
\hline $\mathbf{6}$ & $\begin{array}{l}\text { Rata-Rata Nilai } \\
\text { Persentase (\%) } \\
\text { QoS }\end{array}$ & $\mathbf{9 3 , 4 2 ~ \%}$ & $\mathbf{1 0 0 \%}$ \\
\hline
\end{tabular}

\section{PENUTUP}

Metode penentu Quality of Service pada Cisco Router terdiri dari dua metode yaitu Traffic Policing dan Traffic Shaping. Tujuan dari dibuatnya metode ini adalah untuk membatasi besar bandwidth yang diberikan kepada pelanggan dari sebuah penyedia layanan internet (ISP) atas dasar Term of Service (ToS) dan Service Level Agreement (SLA) antara kedua belah pihak dan kemampuan ISP tersebut.

Setelah melakukan analisa QoS pada Cisco Router ISP dengan menggunakan analisis deskriptif yang membandingkan antara metode Traffic Policing dan Traffic Shaping menggunakan beberapa parameter QoS seperti: Throughput, Packet Loss, Delay (Latency) dan Jitter. Maka metode Traffic Shaping lebih baik dari pada metode Traffic Policing. Adapun Nilai Persentase (\%) QoS sebesar 100\% untuk Traffic
Shaping dengan Indeks Sangat Baik dan 93,42\% untuk Traffic Policing dengan Indeks Baik.

Mengingat penggunaan metode QoS pada cisco router tidak terlepas dari beberapa kelebihan dan kekurangan, adapun beberapa saran yang patut dipertimbangkan untuk proses pengembangan penelitian selanjutnya antara lain :

1. Traffic Shaping yang digunakan saat ini yaitu berjenis Class-Based Traffic Shaping sudah cukup baik akan tetapi penulis memberikan perancangan Traffic shaping berjenis Distribution Traffic Shaping sebagai saran berikut diberikan alasan-alasan kenapa harus mengunakan Distributed Traffic Shaping.

2. Penulis pun tidak menutup kemungkinan akan adanya metode penentu QoS yang baru ataupun adanya pengembangan dari metode yang lama untuk memperbaiki kesalahannya agar tersedia layanan sambungan internet yang murah, efektif dan efisien bagi pihak pelanggan maupun pihak ISP.

\section{DAFTAR PUSTAKA}

[1] Cenggoro, Tjeng Wawan, and Ida Siahaan. "Dynamic Bandwidth Management Based on Traffic Prediction Using Deep Long Short Term Memory."Science in Information Technology (ICSITech), 2016 2nd International Conference on. IEEE, 2016.

[2] Sofana, I. "Cisco CCNA \& Jaringan Komputer". Bandung : Informatika Bandung, 2014

[3] Ríadi, Imam, dkk. "Implementasi Quality of Service menggunakan Metode Hirarchical Toket Busket". JUSI Vol 1, No. 2, Yogyakarta, 2011

[4] Arifin, Yunus. "Implementasi Quality of Service dengan Metode HTB (Hierarchical Token Bucket) pada PT. Komunika Lima Duabelas." JELIKU-Jurnal Elektronik Ilmu Komputer Universitas Udayana 1.2 (2013): 1-7.

[5] A. Kurniawan, "Network Forensics : Panduan Analisis dan Investigasi Paket Data Jaringan menggunakan Wireshark", Yogyakarta: Andi, 2012.

[6] O. Shimonski, "The Wireshark Field Guide : Analyzing and Troubleshooting Network Traffic", Syngress, 2009.

[7] Andrew S.Tanenbaum, "Computer Networks", 4th Edition, p88, Prentice Hall of India, 2003.

[8] Silitonga, Parasian, dkk. "Analisis QoS (Quality of Service) Jaringan Kampus dengan Menggunakan Microtic Routerboard". Jurnal TIMES; RSUP Haji Adam Malik Medan, 2014

[9] Wei, Yongtao, Jinkuan Wang, and Cuirong Wang. "A traffic prediction based bandwidth management algorithm of a future internet architecture." Intelligent Networks and Intelligent Systems (ICINIS), 2010 3rd International Conference on. IEEE, 2010.

[10] Astuti, Yenni. "Analisis Throughput Trafik Data Menggunakan Model Sistem Sharing." Jurnal Teknologi 9.2 (2017): 124-131.

[11] Sudarmaji. "Bandwidth Management Network Design Of Wireless Local Area Network (Wlan) Diploma 3 Program Information Management Universitas Muhammadiyah Metro." Jurnal Mikrotik; Program Diploma 3 Manajemen Informatika UM Metro, 2014.

[12] Imansyah, Surya. "Bandwidth Management Dengan Menggunakan Mikrotik Router OS pada RTRW-Net". Skripsi Teknik Informatika Universitas Islam Negeri Syarif Hidayatullah Jakarta, 2010. 
[13] Fitriastuti, Fatsyahrina, dkk. "Implementasi Bandwidth Management dan Firewall System Menggunakan Mikrotik OS 2.9.27’. Jurnal. Universitas Janabadra. Yogyakarta, 2013.
[14] Sentosa, Budi. "Manajemen Bandwidth internet dan intranet". http://kambing.ui.ac.id/onnopurbo/library/library-ref-ind/refind2/network/bwmanagement.pdf, 3 Nov 2015.

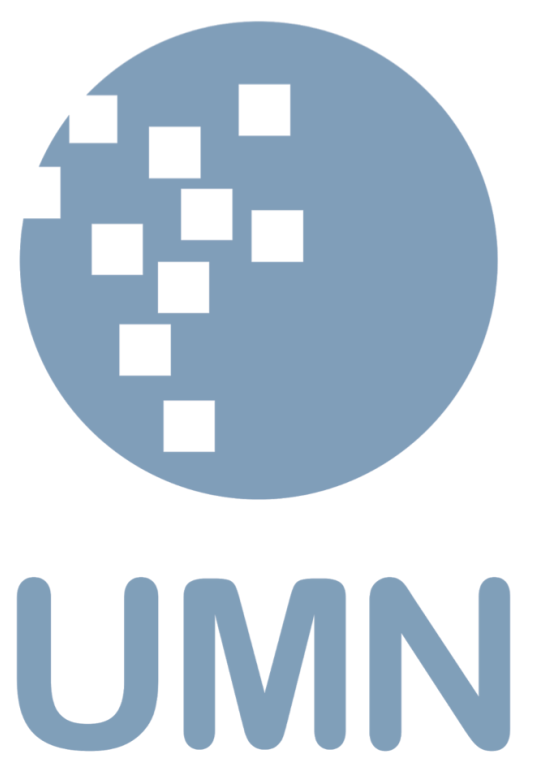

